\title{
LINKS BETWEEN ENTREPRENEURIAL CULTURE, INNOVATION, AND PERFORMANCE: THE MODERATING ROLE OF FAMILY FIRMS
}

\author{
Antonio L. Leal-Rodríguez (alleal@uloyola.es) Universidad Loyola Andalucía. \\ Gema Albort-Morant (galbort@us.es) Universidad de Sevilla. \\ Silvia Martelo-Landroguez (smartelo@us.es) Universidad de Sevilla.
}

\begin{abstract}
:
The relationships between corporate entrepreneurship, innovation and performance have been previously addressed by the literature. However, they have yielded mixed and often inconclusive results. The purpose of this paper is hence to empirically test a model that links entrepreneurial culture, innovation outcomes and business performance. In this model, the family nature of firms is subsequently included as a moderator variable. The empirical investigation is based on a sample of 145 family firms from the automotive components manufacturing sector in Spain. This study uses Partial Least Squares (PLS) path-modeling to test our research model and hypotheses. Our results reveal the increasing importance of fostering an entrepreneurial culture within family firms in order to yield innovation processes and performance.
\end{abstract}

KEYWORDS: Entrepreneurial culture; Innovation outcomes; Business performance; Family business; Partial least squares

\section{INTRODUCTION}

Although both entrepreneurship and managerial issues occupy core positions with regard to organizations' and nations' levels of wealth and success, it is surprising that traditionally such fields of research have developed largely independently from each other (Audretsch et al., 2005). Conversely, innovation and entrepreneurship should be grasped as continuous and complementary processes. On the one hand, innovation constitutes a vital source of entrepreneurship, and on the other hand, entrepreneurship allows innovation to flourish and to realize its economic and social value (Schmitz et al., 2016).

Nowadays, organizations are forced to compete within a scenario characterized by its high doses of complexity, dynamism, globalization, volatility and uncertainty. According to Leal-Rodríguez et al. (2015, p. 803), "innovation enables firms to protect themselves from highly uncertain and unstable scenarios, making firms more capable of seeking new opportunities and exploiting existing ones more efficiently (Matzler et al., 2013)". Furthermore, under these circumstances, organizational innovativeness becomes a critical issue while attempting to create and sustain competitive advantages, which in turn might lead to enhance overall business performance (Leal-Rodríguez and Albort-Morant, 2015). Consequently, it is noteworthy to grasp what ultimately determines innovation and why some organizations are more innovative and develop more entrepreneurial projects than others.

The link between organizational culture and firms' innovativeness has been widely addressed by the literature. However, whether its effect is positive or negative has remained unclear until now. Organizational culture is defined as a system of shared values, opinions, rules and beliefs within an organization, which are considered the social glue that links the company as a whole (Lau et al., 2002). Several studies consider that organizational culture is a key driver of innovation and the literature offers strong evidence with regard to 
this positive link (Deshpandé et al., 1993; Hernández-Mogollón et al., 2010). Nevertheless, organizational culture can either favor or hinder innovativeness. A firm that really intends to be innovative must have an organizational culture that strongly allows and supports innovation (Santos-Vijande and Alvarez-Gonzalez, 2007).

In this research, we focus on a particular cultural typology, which is labeled as entrepreneurial culture (EC). This culture consists of a set of internal and subjective factors linked with the firms' and managers' entrepreneurial orientation. EC influences the behavior of managers and staff in charge of choosing the adequate strategies in the processes of innovation and superior performance attainment (Yarbrough et al., 2011). Thus, companies assign a high priority to their culture since it can be a critical source of competitive advantages (Wei et al., 2014).

Several studies posit that EC enables the development of the entrepreneur's capabilities, which in turn help to build and maintain the firms' competitiveness and superior performance (Teece, 2009; Schein, 2010). Minguzzi and Passaro (1993) distinguish between two components of EC: (i) the cultural stock, and (ii) the cultural rate. On the one hand, the first component is comprised of the entrepreneur's personal qualities (Kirzner, 1979), management style (Zahra, 1993), and level of education acquired. Entrepreneurs need to act dominantly, independently and autonomously to achieve their goals. Entrepreneurship is often linked with personal traits such as innovativeness, creativity, imagination, impatience, proactivity and opportunism as agents of change (Chell et al., 1991). On the other hand, the second component consists of the behavioral features of the entrepreneur, which permit the enhancing of personal knowledge, as well as the abilities of assessing, criticizing, and recognizing their limits in terms of decision-making (Minguzzi and Passaro, 2001). These two components of EC significantly affect the firm's organizational learning capability, which often leads to changes in the organization's behavioral models.

In addition to personality and behavioral factors associated with the entrepreneur and the rest of the firm's members, there is a set of contextual factors -for instance, the economic environment, family history, prior professional experience and background, national culture and traditions, legal framework, political systems and organizational trajectory - which can affect the EC of firms (Berger, 1991). In this vein, we identified the existence of a gap within this research topic. There is plenty of literature addressing the direct links between entrepreneurship, innovation and performance. Yet there is a scarcity of empirical works aimed at understanding the impact that these contextual variables exert on these issues. With this goal in mind, we mean to explore how the family nature of the firm (FAM) actually may affect entrepreneurship, innovativeness, and performance.

Prior research lacks from consensus with regard to the relationship between the family nature of the firm and entrepreneurship (Casillas et al., 2011). On the one hand, firms possessing a strongly implemented family culture (Zahra et al., 2004; Nordqvist et al., 2008) and a highly centralized organizational structure characterized by the cooperative endeavor of managers and owners to foster proactive and innovative behavior (Salvato, 2004), may promote entrepreneurship at the firm level. On the other hand, high doses of traditionalism and risk-aversion, features commonly inherent to family firms (Naldi et al., 2007), may hinder the firm's ability to create and maintain an entrepreneurship approach. Thus, there is a remarkably demand for conducting a more in-depth assessment of the link between the family nature of firms, entrepreneurship, innovation and performance.

In the same way that organizations can learn by means of their members' capability to learn (Senge, 2006), a firm's corporate culture reflects their members' set of cultural values and approaches. Therefore, although in this study we rely on individuals' perceptions about organizational culture, firm innovativeness and levels of performance, our unit of analysis is the firm level.

The main purpose of this work is hence to explore in depth the relationships between the entrepreneurial culture of firms (EC), their innovation outcomes (IO) and business performance (BP). Furthermore, the family nature of the firm (FAM) is considered as a moderator variable in the direct EC-IO and IO-BP relationships included within our proposed model. Therefore, this study develops a model that: (i) examines 
the relationship between the firm's EC and its IO, (ii) examines the relationship between the firm's IO and its overall BP; and (iii) analyzes the moderating role of FAM on the previously posited relationships. This study is structured into the following sections. The next section presents a review of the literature and the study's assumptions. The third section describes the sample and methodology used. The fourth section presents the empirical results of the study. Finally, the fifth section offers the discussion of the results, the final conclusions, and future lines of research.

\section{LITERATURE REVIEW AND HYPOTHESES DEVELOPMENT}

Our research focuses on the links between entrepreneurial culture, innovation outcomes, and business performance. We propose positive relationships between these constructs, and we further suggest that the family nature of firms impact these relationships. Our specific research question is: Do family firms actually reinforce overall business performance through enhancing entrepreneurship and innovation? The proposed research model is depicted in Figure 1.

-Insert Figure 1-

\subsection{Linking Entrepreneurial Culture and Innovation Outcomes}

The role of organizational culture is widely acknowledged as fundamental for the development of innovation (Turró et al., 2014). Innovation and entrepreneurship are two concepts that often appear narrowly linked within the literature. Since innovation is frequently labeled as an intrinsic condition in an entrepreneurial process, a firm's ability to come up with successful innovative products might lead us to consider this tie in parallel. In this line, Drucker (1985) argues that innovation and entrepreneurship, taken together, are the driving forces underlying economic growth and success of firms and society at large.

Peris-Ortiz (2009) coins the term corporate entrepreneurship to refer to the capability possessed by those groups of managers and staff who collaborate and make decisions with the aim of boosting entrepreneurship, learning and innovation at the firm level. Such capability is linked to the capacity to discover or create opportunities; the ability to exploit these opportunities on the basis of social networks and institutional capital (Audretsch and Monsen 2008); and the activity of organizational renewal, which allows continuous improvement and firm innovativeness. Besides, Albort-Morant and Rey-Martí (2015) label a firm's entrepreneurial capital to refer to those employees who innovate and assume risks with the purpose of contributing to their firm's advance.

Entrepreneurial culture represents the firm's orientation toward the exploration of new resources, innovation, and the creation of new products (Ireland et al., 2006; Wei et al., 2013). Companies with an entrepreneurial culture, as opposed to more conservative companies, innovate audaciously and regularly (Miller and Friesen, 1982), are proactive, and assume risks to carry out strategies oriented to developing innovative products, services or processes (Lee and Peterson, 2001). In this line, EC includes risk-taking, putting up with failure, dealing with uncertain environments, competing in complex settings, pursuing opportunities, embracing flexibility, and creating the ambiance that fosters innovation (Hamel, 2002; Genç, 2012). EC promotes the innovative firms' behavior in all its areas, which allows the anticipation of market trends and opportunities.

Entrepreneurial culture supports the development of new ideas, enables experimenting, and provides new solutions to problems linked with entrepreneurs' creative processes that ultimately determine the strength of organizational innovativeness (Lee and Peterson, 2001). Fostering an entrepreneurial culture may assist the organization in the process of attaining radical innovations. These companies that invest in EC will experience positive results in terms of new technologies, products, services or processes. On the basis of the arguments above, we posit that entrepreneurial culture is positively linked with innovation outcomes and we propose the following hypothesis (see Figure 1): 
H1: Entrepreneurial culture (EC) is positively related to innovation outcomes (IO).

\subsection{Linking Innovation Outcomes and Business Performance}

The literature offers plenty of empirical studies assessing the innovation-performance relationship. However, it has frequently presented mixed findings. Several studies reveal that innovation does not influence business performance (Birley and Westhead, 1990; Heunks, 1998) or find a negative impact of innovation in performance (McGee et al., 1995; Vermeulen et al., 2005). Nevertheless, other research finds a positive link between both variables ( $\mathrm{Li}$ and Atuahene-Gima, 2001; Guo et al., 2005; Leal-Rodriguez et al., 2015).

An innovative approach allows firms to deal better with extremely complex, unstable and highly uncertain environments, and hence, companies are able to look for new opportunities and explore the existing ones more efficiently (Matzler et al., 2013). This is in line with findings from Brown and Eisenhard (1995), who stated that innovative companies are capable of responding to challenges more rapidly and better than less innovation-oriented firms.

Organizational innovation involves supporting and being permeable to innovation in terms of developing new products or processes, opening new markets, or simply developing new strategic paths (Wang and Ahmed, 2004). Innovation always implies a certain degree of risk, and its application does not always guarantee success. Incorporating innovation as a proactive strategy allows a firm to respond to environmental or sectorial changes, technological advances and anticipate customers' needs and demands (Jansen et al., 2006). Therefore, all these actions are expected in the long term to differentiate innovative companies from their competitors, hence improving their business performance.

Our position is in line with those authors who suggest the existence of a positive link between firm innovativeness and business performance. We understand that fostering organizational innovativeness may attain better results and enhance a firm's overall performance. Our reasoning lies on the assumption that the firm's adoption of an innovation-driven approach might lead them to be more prepared to deal with the currently uncertain and turbulent competitive scenario and enable them to reach and maintain competitive advantages in the long term (Leal-Rodríguez et al., 2015). Thus, the companies that proactively embrace innovation-based strategies show a decisive response to sectorial trends, industrial changes, technological advancements and the anticipation of customers' demands.

According to the above discussion, we posit that innovation outcomes would positively affect business performance. This hypothesis is as follows (see Figure 1):

H2: Innovation outcomes (IO) are positively related to business performance (BP).

\subsection{The moderating effect of the family nature of the firm}

With regard to the relationships raised in this study, it should be highlighted that there are prior studies that have stressed the importance of exploring the EC construct's dimensionality among family firms (Naldi et al., 2007). Nonetheless, the literature has failed to empirically test the moderating role of family business on the EC-IO link.

There is some controversy with regard to the conceptualization of family business, and consequently, family business researchers have been forced to import theories from the fields of anthropology, economics, sociology, psychology, organizational theory, organizational behavior, entrepreneurship, and strategic management (Zahra, 2016). We define family firms as those companies where a family group controls the company through possessing a clear majority of shares and representation on the managerial board (Westhead and Cowling, 1999). Family firms combine the desire to maintain the control - management- and 
the property -ownership-of the company by the family (Steier, 2003). In such companies, the owners maintain a considerable impact on the business activities and decisions. Nevertheless, there are discrepancies with regard to the nature of family businesses. Authors such as Aronoff and Ward (1997), Sharma et al. (1997) and Hall et al. (2001), consider that family businesses are often typified by being conservative, resistant to change and introverted, which would be contrary to what is regarded as an entrepreneur. The fear of losing the family wealth can prevent family-driven firms from participating in entrepreneurial activities (Sharma et al., 1997).

One possible explanation of the appearance of mixed and often inconclusive results in the field of family business is perhaps that previous studies fail to effectively distinguish among the different typologies of family firms (Westhead \& Howorth, 2007). There is a significant degree of heterogeneity among family firms. Thus, strategic behaviors and policies may differ, not only between family and non-family firms, but also between distinct family firms (Arregle et al., 2012). A noteworthy distinguishing trait is the varying level of family ownership and control. This way, studies have traditionally focused on family firms characterized by unilateral family control (i.e., complete or majority ownership by the family). Therefore, studies examining family business should state (i) whether the unit of analysis is shaped by an individual practitioner or it involves several associated partners; (ii) whether it is a family-controlled firm or a familyinfluenced company; and (iii) the degree of internationalization of the firm. In this vein, our study is focused on Spanish firms belonging to the automotive components and equipment manufacturing industry, which is eminently shaped by family controlled SMEs with a relatively high degree of internationalization, as many of their customers are large globally distributed automobile fabricants.

Recent research reveals that entrepreneurial activity is a common feature of many family businesses (Hall et al., 2001; Steier, 2003; Zahra, 2005). Litz (1995), Aldrich and Cliff (2003), Rogoff and Heck (2003) or Zahra et al. (2004) are examples of authors who argue that family businesses are seen as examples of entrepreneurial and innovative companies, given that they often take risks to increase their overall performance. In addition, there is a growing number of studies that highlight the specific entrepreneurial features of family firms (Hall et al., 2001; Zahra et al., 2004; Kellermanns and Eddleston, 2006). Family firms are marked by having an entrepreneurial culture. Family ties have a positive effect on the recognition of business opportunities (Aldrich and Cliff, 2003) and entrepreneurial spirit (Zahra et al., 2004).

Furthermore, we can establish links between family firms and small companies, as the majority of family businesses are SMEs. In this vein, Schumpeter (1934) pointed out that SMEs might constitute a vehicle for entrepreneurship, as such type of firms present some clear advantages with regard to developing innovative activity compared to large-size corporations. Following Ribeiro-Soriano and Roig-Dobon (2009), the major advantages of SMEs with this regard can be summarized in the following ones: (i) small firms tend to be less bureaucratic, without those often redundant and unnecessary layers that block daring ventures, more typical from larger and more structured corporations; (ii) plenty of technological advances rely upon countless detailed inventions that comprise from components and raw materials to sophisticated manufacturing techniques. The income potentially derived from investing in such narrow and detailed advances are often too modest to capture the attention of large companies; and (iii) it is easier to maintain high levels of excitement within small firms, where the ties between challenges, employees' motivation and potential rewards remain tight. Besides, large corporations also present certain advantages for developing organizational innovation, as they normally have more resources at their disposal and can assign larger budget headings to R\&D purposes (Schumpeter, 1934).

On the basis of the above statements, we sustain that the family nature of the firm positively moderates (reinforcing) the relationship between entrepreneurial culture and innovation outcomes, and the relationship between innovation outcomes and business performance. Thus, we posit the following hypotheses (see Figure 1).

H3: The relationship between EC and IO is positively moderated by the family nature of the firm (FAM).

H4: The relationship between IO and BP is positively moderated by the family nature of the firm (FAM). 


\section{METHODOLOGY}

\subsection{Data collection and sample}

Data for this research comes from a sample of firms belonging to the automotive components manufacturing industry in Spain. To obtain the sample we used a list from Sernauto, the Spanish Association of manufacturers of equipment and components for the automotive industry. This sector is made up of a total of 906 companies, 418 of which fulfilled our selection criteria (i.e., being knowledge-intensive companies that pursue innovation). We received 145 usable surveys after two mailings (a 34.7\% response rate).

There is much debate on how to define family firms. According to Casillas et al. (2011), two criteria stand out among all the existing criteria for the definition of family firms: i) ownership, and ii) self-definition. The first is objective while the second is subjective. In this study, we have asked respondents to self-report if they perceive the firm as a family business. We have chosen self-perception as a family business in place of objective measures as there is a basis for considering the owner-manager's perception that the firm is a family business as an important defining variable (Cooper et al., 2005; Uhlaner, 2005; Dibrell and Moeller, 2011; Zellweger and Sieger, 2012; Madison et al., 2014). Top managers answered the questionnaires. Our sample represents 145 self-reported family firms. Table 1 presents a series of demographic data with regard to the sample.

-Insert Table 1-

\subsection{Measures}

The research survey design is based on the theoretical review in Section 2. This study essentially adapts previously validated scales in which the items and responses appear on a seven-point Likert scale ranging from $1=$ I completely disagree to $7=$ I completely agree

We measured entrepreneurial culture (EC) by adapting six items from a study performed by Cameron and Quinn (1999). Innovation outcomes (IO) were measured using eight items adapted from a study carried out by Prajogo and Ahmed (2006). Business performance (BP) was obtained with a five-item scale of Lee and Choi (2003). Finally, a single item was used ("to what extent do you believe your company is a family business?") in order to ask if the respondent perceived the firm as a family business. Although multiple measures are preferred, a single item measure of self-perception is anchored in prior research (Cooper et al., 2005; Uhlaner, 2005; Casillas et al., 2011; Dibrell and Moeller, 2011; Zellweger and Sieger, 2012; Madison et al., 2014). Appendix A provides the scale items.

\subsection{Data analysis}

In order to test the research model and hypotheses, we rely on the use of partial least squares (PLS), a variance-based structural equation modeling (SEM) method. PLS is a suitable technique for our research purposes due to the following reasons (Roldán and Sánchez-Franco, 2012): (i) the sample size $(\mathrm{n}=145)$ is small; (ii) the study is focused on the prediction of the dependent variables; (iii) the research model entails considerable complexity with regard to the type of relationships in the hypotheses; and (iv) this study uses scores of latent variables in the subsequent analysis for predictive purposes. We used the SmartPLS 2.0 software (Ringle et al., 2005) for the assessment of both the measurement model and the structural model.

\section{RESULTS}


The assessment and interpretation of PLS models have two stages: (1) assessing the reliability and validity of the measurement model; and (2) evaluating the structural model.

\subsection{Measurement model}

Evaluating the measurement model involves the assessing for reliability and validity. Our results reveal that the measurement model meets all the requirements. First, the reflective individual items reliability requisite is supported as all the standardized loadings are greater than 0.707 (Carmines and Zeller, 1979) (Table 2). Second, the construct reliability requirement is also satisfied since all reflective constructs have composite reliabilities greater than 0.7 (Nunnally and Bernstein, 1994) (Table 2). Besides, these latent variables reach convergent validity because their average variance extracted (AVE) measures surpass the 0.5 level (Fornell and Larcker, 1981) (Table 2). In addition, all the variables comply with the discriminant validity requirement (Table 3).

-Insert Table 2-

-Insert Table 3-

\subsection{Structural model}

The structural model is assessed on the basis of the algebraic sign, magnitude and significance of the structural path coefficients. The $\mathrm{R}^{2}$ values assess for predictive significance. Table 4 shows the explained variance $\left(\mathrm{R}^{2}\right)$ in the endogenous variables and the path coefficients for the two models under study. Model 1 presents the direct relationships between the constructs under study, and Model 2 indicates these relationships taking into account the moderating effect of the family nature of the firm (FAM). The 5000 resamples Bootstrapping procedure provides t-values that allow the evaluation of the statistical significance of the relationships included in the research model (Roldán and Sánchez-Franco, 2012).

The two direct effects hypothesized in Figure 2.A. (Model 1) are significant.We therefore find support for both hypotheses H1 and H2 (Table 4). Regarding Figure 2.B (Model 2), in order to test the moderating effect of FAM on the EC-IO and IO-BP links (H3 and H4), we followed the product-indicator technique proposed by Henseler and Fassott (2010). In the same manner as in regression analysis, we multiply the predictor (EC or IO) and the moderator (FAM) variables in order to obtain the interaction term. In addition, we followed Chin et al.'s (2003) recommendation of standardizing the product indicators. The results reveal that, the coefficients of both interaction hypotheses are statistically significant (Table 4). The $\mathrm{R}^{2}$ for Model 2 are then compared to the $\mathrm{R}^{2}$ for Model 1, which excludes the interaction term (Chin, 1998). The difference in the $\mathrm{R}$ square lets us evaluate the overall effect size $f^{2}$ for the interaction effect. The effect size $f^{2}$ is obtained through the following formula: $f^{2}=\left(\mathrm{R}^{2}\right.$ included $-\mathrm{R}_{\text {excluded }}^{2} / 1-\mathrm{R}^{2}$ included. Values of $f^{2}$ up to $0.02,0.15$ and 0.35 indicate that the interaction term has, respectively, a weak, moderate, or strong effect on the criterion variable. In our case, the interaction terms achieves $f^{2}$ values of 0.032 and 0.108 . Therefore, we find support for hypothesis $\mathrm{H} 3$ and $\mathrm{H} 4$ and sustain that FAM exerts a moderate effect on the criterion variables.

- Instert Figure 2 -

-Insert Table 4-

\section{DISCUSSION AND CONCLUSIONS}


This paper explores the links between entrepreneurial culture (EC), innovation outcomes (IO) and business performance (BP), and, subsequently, assesses the moderating role of the family nature of firms (FAM) in these links. The firms' entrepreneurial culture, innovation outcomes and overall business performance have been previously linked and assessed in the scientific literature. Nevertheless, there is a paucity of research studies that empirically analyze the moderating effect of contextual factors such as the family nature of firms (FAM). This is the gap that we aim to fill with this study. Therefore, this paper's goal is to shed light on the following research question: Do family firms actually reinforce overall business performance through enhancing entrepreneurship and innovation?

According to Sirmon and Hitt (2003), family firms embrace an idiosyncratic set of resources shaped by the interaction of business and family related matters. This interaction might affect the ways in which family firms manage and allocate resources and could bring them both advantages and disadvantages. Chua et al. (1999) posit that the distinctiveness of family firms is due to their particular patterns of ownership, governance, management and succession, which in turn might influence the firm's goals, strategies and structure. This assumption is in line with what Gudmundson et al. (2003) hypothesizes, sustaining that organizational innovativeness might be different between family and non-family firms. Certainly, family firms involve some features that may facilitate or strengthen the EC-IO and IO-BP links. These features -for example, trust, the deployment of synergies and information and knowledge gathering and sharing- could hence multiply such relationships (Silva and Majluf, 2008).

However, the role of an organization's family nature in enhancing or hindering innovation and entrepreneurship still remains unclear. Some scholars posit a negative link between family firms and innovation, whereas others suggest a positive link between both variables. Family firms are mainly characterized by being small-medium-sized enterprises (SMEs). Several studies point out a current trend consisting of the irruption of SMEs bringing innovative products, services and processes. A significant number of SMEs survive nowadays thanks to their innovative spirit (De Jong and Marsili, 2006; Laforet, 2013). Although SMEs often lack the basic means and know-how to invest in innovation, they have a big advantage compared to large companies: their size makes them more flexible and less bureaucratized. This might permit family firms to foster entrepreneurship and innovation (Laforet, 2008).

The findings of this study can be grouped in terms of (i) providing support for the hypothesized EC-IO and IO-BP direct links; (ii) clarifying the impact exerted by FAM -hypothesized as a moderator variable- on these ties; and (iii) providing a better knowledge and understanding of the linkages between entrepreneurship, innovation and performance within the particular context of the Spanish automotive components manufacturing industry. The results hence support the hypotheses formulated in this study. The family nature of firms defines a new area of potential competitive advantages, acting as an enabler of entrepreneurship and innovativeness.

Some managerial implications can be sustained. First, it should be noted that fostering an entrepreneurial culture could be considered a facilitator of organizational innovativeness. The firms' endeavor and commitment to becoming a dynamic and entrepreneurial entity where individuals are willing to bet on their ideas and assume risks, promoting individual initiative and seeking to develop novel and unique products or services, may exert a significant influence on organizational innovativeness enhancement. Hence, firms that aim to promote innovation and strengthen their business performance might firstly invest in promoting an entrepreneurial culture. Second, although family firms may present some drawbacks as to enabling internal innovation and entrepreneurship, managers should stimulate the features that may reinforce these issues - for instance, the establishment and development of synergies and knowledge sharing.

The interpretation of the results presented and discussed in this research is subject to several limitations. First, although this study provides evidence of causality, it fails to test causality, given that it is the researcher who always assumes the direction of causal relationships. Second, this research is based on the perceptions of survey respondents and we only employed a single method to elicit these insights. Finally, this study is developed within a specific economic sector (the automotive components manufacturing industry) and a 
specific geographical scenario (Spain). Consequently, researchers should be cautious when generalizing these conclusions and insights to different contexts.

In summary, this study emphasizes the role of family firms as an enabler of entrepreneurship and innovation, and, subsequently, as a driver of performance. Notwithstanding, future longitudinal works could be addressed in order to confirm these insights. Furthermore, it might be interesting to expand this study by exploring the impact exerted by the variables included within the research model on objective performance indicators, financial ratios being an example (e.g., ROA, ROE, etc.). Finally, this research could be extended to a different sector or geographical context in order to gain more evidence to sustain our hypotheses.

\section{REFERENCES}

Albort-Morant, G. \& Rey-Martí, A. (2015). The Development of ICTs and the Introduction of Entrepreneurial Capital. In Annual Conference of the Global Innovation and Knowledge Academy (pp. 84-92). Springer International Publishing.

Aldrich, H. E. \& Cliff, J. E. (2003). The pervasive effects of family on entrepreneurship: Toward a family embeddedness perspective. Journal of Business Venturing, 18(5), 573-596.

Arregle, J. L., Naldi, L., Nordqvist, M. \& Hitt, M. A. (2012). Internationalization of family controlled firms: A study of the effects of external involvement in governance. Entrepreneurship Theory and Practice, 36(6), 1115-1143.

Aronoff, C. E. \& Ward, J. L. (1997). Preparing your Family Business for Strategic Change. Family Business Leadership Series, 9. Marietta, GA: Business Owner Resources.

Audretsch, D. B. \& Monsen, E. (2008). Entrepreneurship Capital: A Regional, Organizational, Team and Individual Phenomenon. In: R. Barrett and S. Mayson (Eds.). International Handbook of Entrepreneurship and HRM, pp. 47-70, Cheltenham, England: Edward Elgar.

Audretsch, D. B., Castrogiovanni, G. J., Ribeiro, D. \& Roig, S. (2005). Linking entrepreneurship and management: Welcome to the International Entrepreneurship and Management Journal. International Entrepreneurship and Management Journal, 1(1), 5-7.

Berger, B. (1991). The Culture of Entrepreneurship. San Francisco, CA: ICS Press.

Birley, S. \& Westhead, P. (1990). Growth and performance contrasts between 'types' of small firms. Strategic Management Journal, 11(7), 535-557.

Brown, S. L. \& Eisenhard, K. M. (1995). Product development: Past research, present findings, and future directions. Academy of Management Review, 20(2), 343-378.

Cameron, K. S. \& Quinn, R. E. (1999). Diagnosing and Changing Organizational Culture. Reading, MA: Addison Wesley.

Carmines, E. G. \& Zeller, R. A. (1979). Reliability and Validity Assessment. Beverly Hills, CA: Sage.

Casillas, J. C., Moreno, A. M. \& Barbero, J. L. (2011). Entrepreneurial orientation of family firms: Family and environmental dimensions. Journal of Family Business Strategy, 2(2), 90-100.

Chell, E., Haworth, J. \& Brearley, S. (1991). The Entrepreneurial Personality: Concepts, Cases and Categories. London: Routledge.

Chin, W. W. (1998). The partial least squares approach to structural equation modeling. Modern Methods for Business Research, 295(2), 295-336. 
Chin, W. W., Marcolin, B. L. \& Newsted, P. R. (2003). A partial least squares latent variable modeling approach for measuring interaction effects: Results from a Monte Carlo simulation study and an electronic-mail emotion/adoption study. Information Systems Research, 14(2), 189-217.

Chua, J. H., Chrisman, J. J. \& Sharma, P. (1999). Defining the family business by behavior. Entrepreneurship Theory and Practice, 23(4), 19-40.

Cooper, M. J., Upton, N. \& Seaman, S. (2005). Customer Relationship Management: A Comparative Analysis of Family and Nonfamily Business Practices. Journal of Small Business Management, 43(3), 242-256.

De Jong, J. P. \& Marsili, O. (2006). The fruit flies of innovations: A taxonomy of innovative small firms. Research Policy, 35(2), 213-229.

Deshpandé, R., Farley, J. U. \& Webster Jr, F. E. (1993). Corporate culture, customer orientation, and innovativeness in Japanese firms: a quadrad analysis. Journal of Marketing, 57(1), 23-37.

Dibrell, C. \& Moeller, M. (2011). The impact of a service-dominant focus strategy and stewardship culture on organizational innovativeness in family-owned businesses. Journal of Family Business Strategy, 2(1), 43-51.

Drucker, P. (1985). Innovation and Entrepreneurship. New York, NY: Harper \& Row.

Fornell, C. \& Larcker, D. F. (1981). Evaluating structural equation models with unobservable variables and measurement error. Journal of Marketing Research, 18(1), 39-50.

Genç, K. Y. (2012). The response of the entrepreneurship to the changing business environment: Strategic entrepreneurship. International Journal of Economic and Administrative studies, 5(9), 71-83.

Gudmundson, D., Tower, C. B. \& Hartman, E. A. (2003). Innovation in small businesses: Culture and ownership structure do matter. Journal of Developmental Entrepreneurship, 8(1), 1-17.

Guo, R. J., Baruch, L. \& Zhou, N. (2005). The valuation of biotech IPOs. Journal of Accounting, Auditing \& Finance, 20(4), 423-459.

Hall, A., Melin, L. \& Nordqvist, M. (2001). Entrepreneurship as radical change in the family business: Exploring the role of cultural patterns. Family Business Review, 14(3), 193-208.

Hamel, G. (2002). Leading the Revolution: How to Thrive in Turbulent Times by Making Innovation a Way of Life. Boston, MA: Harvard Business School Press.

Henseler, J. \& Fassott, G. (2010). Testing Moderating Effects in PLS Path Models: An Illustration of Available Procedures. In: V.E. Vinzi, W.W. Chinn, J. Henseler and H. Wang (Eds). Handbook of Partial Least Squares, pp.713-735, Berlin, Germany: Springer Berlin Heidelberg.

Hernández-Mogollon, R., Cepeda-Carrión, G., Cegarra-Navarro, J. G. \& Leal-Millán, A. (2010). The role of cultural barriers in the relationship between open-mindedness and organizational innovation. Journal of Organizational Change Management, 23(4), 360-376.

Heunks, F. J. (1998). Innovation, creativity and success. Small Business Economics, 10(3), 263-272.

Ireland, R. D., Kuratko, D. F. \& Morris, M. H. (2006). A health audit for corporate entrepreneurship: Innovation at all levels: Part I. Journal of Business Strategy, 27(1), 10-17.

Jansen, J. J., Van Den Bosch, F. A. \& Volberda, H. W. (2006). Exploratory innovation, exploitative innovation, and performance: Effects of organizational antecedents and environmental moderators. Management Science, 52(11), 1661-1674. 
Kellermanns, F. W. \& Eddleston, K. A. (2006). Corporate entrepreneurship in family firms: A family perspective. Entrepreneurship Theory and Practice, 30(6), 809-830.

Kirzner, I. M. (1979). Perception, Opportunity, and Profit: Studies in Theory of Entrepreneurship. Chicago, IL: University of Chicago Press.

Laforet, S. (2008). Size, strategic, and market orientation affects on innovation. Journal of Business Research, 61(7), 753-764.

Laforet, S. (2013). Organizational innovation outcomes in SMEs: Effects of age, size, and sector. Journal of World Business, 48(4), 490-502.

Lau, C. M., Tse, D. K. \& Zhou, N. (2002). Institutional forces and organizational culture in China: Effects on change schemas, firm commitment and job satisfaction. Journal of International Business Studies, $33,533-550$.

Leal-Rodríguez, A. L. \& Albort-Morant, G. (2015). Capacidad de absorción del conocimiento y resultados de la innovación: Un estudio empírico en empresas españolas del sector de la automoción. Universitas: Gestão e TI, 5(2), 35-47.

Leal-Rodríguez, A. L., Eldridge, S., Roldán, J. L., Leal-Millán, A. G. \& Ortega-Gutiérrez, J. (2015). Organizational unlearning, innovation outcomes, and performance: The moderating effect of firm size. Journal of Business Research, 68(4), 803-809.

Lee, H. \& Choi, B. (2003). Knowledge management enablers, processes, and organizational performance: An integrative view and empirical examination. Journal of Management Information Systems, 20(1), $179-228$

Lee, S. M. \& Peterson, S. J. (2001). Culture, entrepreneurial orientation, and global competitiveness. Journal of World Business, 35(4), 401-416.

Li, H. \& Atuahene-Gima, K. (2001). Product innovation strategy and the performance of new technology ventures in China. Academy of Management Journal, 44(6), 1123-1134.

Litz, R. A. (1995). The family business: Toward definitional clarity. Family Business Review, 8(2), 71-81.

Madison, K., Runyan, R. C. \& Swinney, J. L. (2014). Strategic posture and performance: Revealing differences between family and nonfamily firms. Journal of Family Business Strategy, 5(3), 239251.

Matzler, K., Abfalter, D. E., Mooradian, T. A. \& Bailom, F. (2013). Corporate culture as an antecedent of successful exploration and exploitation. International Journal of Innovation Management, 17(5), 123.

McGee, J. E., Dowling, M. J. \& Megginson, W. L. (1995). Cooperative strategy and new venture performance: The role of business strategy and management experience. Strategic Management Journal, 16(7), 565-580.

Miller, D. \& Friesen, P. H. (1982). Innovation in conservative and entrepreneurial firms: Two models of strategic momentum. Strategic Management Journal, 3(1), 1-25.

Minguzzi, A. \& Passaro, R. (1993). Role and importance of entrepreneurial internationalization. The experiences of small-medium firms of mature industries in southern Italy. In: H. Klandt and D. Müller-Böling (Eds). Internationalizing Entrepreneurship Education and Training, pp. 237-257, Köln-Dortmund, Germany: Förderkreis Gründungs-Forschung. 
Minguzzi, A. \& Passaro, R. (2001). The network of relationships between the economic environment and the entrepreneurial culture in small firms. Journal of Business Venturing, 16(2), 181-207.

Naldi, L., Nordqvist, M., Sjöberg, K. \& Wiklund, J. (2007). Entrepreneurial orientation, risk taking, and performance in family firms. Family Business Review, 20(1), 33-47.

Nordqvist, M., Habbershon, T. G. \& Melin, L. (2008). Transgenerational Entrepreneurship: Exploring Entrepreneurial Orientation in Family firms. In: H. Landström, H. Crijns, E. Laveren and D. Smallbone (Eds). Entrepreneurship, Sustainable Growth and Performance: Frontiers in European Entrepreneurship Research, pp. 93-116, Cheltenham, England: Edward Elgar.

Nunnally, J. C. \& Bernstein, I. H. (1994). Psychometric Theory (3rd ed.). New York, NY: McGraw-Hill.

Peris-Ortiz, M. (2009). An analytical model for human resource management as an enabler of organizational renewal: a framework for corporate entrepreneurship. International Entrepreneurship and Management Journal, 5(4), 461-479.

Prajogo, D. I. \& Ahmed, P. K. (2006). Relationships between innovation stimulus, innovation capacity, and innovation performance. $R \& D$ Management, 36(5), 499-515.

Ribeiro-Soriano, D. \& Roig-Dobon, S. (2009). Linking globalization of entrepreneurship in small organizations. Small Business Economics, 32(3), 233-239.

Ringle, C. M., Wende, S. \& Will, A. (2005). SmartPLS 2.0 (beta), www.smartpls.de.

Rogoff, E. G. \& Heck, R. K. Z. (2003). Evolving research in entrepreneurship and family business: Recognizing family as the oxygen that feeds the fire of entrepreneurship. Journal of Business Venturing, 18(5), 559-566.

Roldán, J. L. \& Sánchez-Franco, M. J. (2012). Variance-based structural equation modeling: guidelines for using partial least squares. In: Research Methodologies, Innovations and Philosophies in Software Systems Engineering and Information Systems, pp. 193-221, IGI-Global.

Salvato, C. (2004). Predictors of entrepreneurship in family firms. The Journal of Private Equity, 7(3), 68-76.

Santos-Vijande, M. L. \& Alvarez-Gonzalez, L. I. (2007). Innovativeness and organizational innovation in total quality oriented firms: The moderating role of market turbulence. Technovation, 27(9), 514532 .

Senge, P. M. (2006). The Fifth Discipline: The Art and Practice of the Learning Organization. Broadway Business.

Schein, E. (2010). Organizational Culture and Leadership. San Francisco, CA: Jossey-Bass.

Schmitz, A., Urbano, D., Dandolini, G. A., de Souza, J. A. \& Guerrero, M. (2016). Innovation and entrepreneurship in the academic setting: a systematic literature review. International Entrepreneurship and Management Journal, (in press).

Schumpeter, J. A. (1934). The Theory of Economic Development: An Inquiry into Profits, Capital, Credit, Interest, and the Business Cycle (Vol. 55). Transaction publishers.

Sharma, P., Chrisman, J. J. \& Chua, J. H. (1997). Strategic management of the family business: Past research and future challenges. Family Business Review, 10(1), 1-36.

Silva, F. \& Majluf, N. (2008). Does family ownership shape performance outcomes? Journal of Business Research, 61(6), 609-614. 
Sirmon, D. G. \& Hitt, M. A. (2003). Managing resources: Linking unique resources, management, and wealth creation in family firms. Entrepreneurship Theory and Practice, 27(4), 339-358.

Steier, L. (2003). Variants of agency contracts in family financed ventures as a continuum of familial altruistic and market rationalities. Journal of Business Venturing, 18(5), 597-618.

Teece, D. J. (2009). Dynamic Capabilities and Strategic Management: Organizing for Innovation and Growth. New York, NY: Oxford University Press.

Turró, A., Urbano, D. \& Peris-Ortiz, M. (2014). Culture and innovation: The moderating effect of cultural values on corporate entrepreneurship. Technological Forecasting and Social Change, 88, 360-369.

Uhlaner, L. M. (2005). The Use of the Guttman Scale in Development of a Family Orientation Index for Small-to-Medium-Sized Firms. Family Business Review, 18(1), 41-57.

Vermeulen, P. A. M., De Jong, J. P. J. \& O'Shaughnessy (2005). Identifying key determinants for new product introductions and firm performance in small service firms. Service Industries Journal, 25(5), 625-640.

Wang, C. L. \& Ahmed, P. K. (2004). The development and validation of the organisational innovativeness construct using confirmatory factor analysis. European Journal of Innovation Management, 7(4), 303-313.

Wei, Y. S., O’Neill, H., Lee, R. P. \& Zhou, N. (2013). The impact of innovative culture on individual employees: The moderating role of market information sharing. Journal of Product Innovation Management, 30(5), 1027-1041.

Wei, Y., Samiee, S. \& Lee, R. (2014). The influence of organic organizational cultures, market responsiveness, and product strategy on firm performance in an emerging market. Journal of the Academy of Marketing Science, 42(1), 49-70.

Westhead, P. \& Cowling, M. (1999). Family firm research: The need for a methodological rethink. Entrepreneurship Theory and Practice, 23(1), 31-56.

Westhead, P. \& Howorth, C. (2007). Types of private family firms: An exploratory conceptual and empirical analysis. Entrepreneurship and Regional Development, 19(5), 405-431.

Yarbrough, L., Morgan, N. A. \& Vorhies, D. W. (2011). The impact of product market strategy organizational culture fit on business performance. Journal of the Academy of Marketing Science, 39(4), 555-573.

Zahra, S. A., Hayton, J. \& Salvato, C. (2004). Entrepreneurship in family vs. non-family firms: A resource based analysis of the effect of organizational culture. Entrepreneurship Theory and Practice, 28(4), 363-381.

Zahra, S. A. (1993). A conceptual model of entrepreneurship as firm behaviour: A critique and extension. Entrepreneurship Theory and Practice, 17(4), 5-21.

Zahra, S. A. (2005). Entrepreneurial risk taking in family firms. Family Business Review, 18(1), 23-40.

Zahra, S. A. (2016). Developing theory-grounded family business research: Some suggestions. Journal of Family Business Strategy, 7(1), 3-7.

Zellweger, T. \& Sieger, P. (2012). Entrepreneurial orientation in long-lived family firms. Small Business Economics, 38(1), 67-84. 
APPENDIX A. QUESTIONNAIRE ITEMS.

Entrepreneurial Culture $(\boldsymbol{E C})(1=\mathrm{I}$ completely disagree with the statement; 7 = I completely agree with the statement). My organization...

- Is a very dynamic and entrepreneurial entity. People are willing to bet on their ideas and take risks

- Is chracterized by fostering entrepreneurship, innovation and assuming risks

- Is typified by promoting individual initiative, risk-taking, innovation, and uniqueness

- Is committed to innovation, development and continuous change

- Values the acquisition of new resources and the creation of new challenges as well as appreciating originality and the search for opportunities.

- Aspires to become leaders in developing unique and innovative products or services.

Innovation outcomes $(\boldsymbol{I O})(1=\mathrm{I}$ completely disagree with the statement; $7=\mathrm{I}$ completely agree with the statement). In my organization...

- The level of novelty (innovation) of the new products is very high

- We use the latest technological innovations in our new products

- We develop new products very quickly

- We have a large number of new products on the market

- We possess a high technological competitiveness in everything we do (greater than all our competitors)

- We adopt the latest technological innovations in our processes very quickly

- The technology used in our processes are highly up-to-date and novel.

- We possess a high rate of change and renewal in our processes, procedures and techniques

Business Performance $(\boldsymbol{B P})(1=\mathrm{I}$ completely disagree with the statement; $7=\mathrm{I}$ completely agree with the statement). In comparison to its main competitors, my company...

- Is more successful

- Possesses a higher market share

- Grows faster

- Is more profitable

- Is more innovative

Family Firm (FAM) (1 = I completely disagree with the statement; 7 = I completely agree with the statement).

- To what extent do you believe your company is a family business? 